Journal of Humanities, Social and Management Sciences (JHSMS)

eISSN: 2788-4791 (online)

https:// doi.org/10.47264/idea.jhsms/2.2.19

Vol. 2, No. 2 (July-December 2021), 255-270

https://www.ideapublishers.org/index.php/jhsms

Research Article

\title{
Water conflict between Pakistan and India: Implications to regional peace and security
}

\author{
Kishwar Munir*1 | Iram Khalid ${ }^{2}$ | Wajeeh Shahrukh ${ }^{3}$ \\ 1. School of Integrated Social science, The University of Lahore, Lahore, Pakistan. \\ 2. Department of Political Science, University of the Punjab, Lahore, Pakistan. \\ 3. Department of Politics and IR, International Islamic University, Islamabad, Pakistan. \\ *Corresponding Author Email: kishwar.munir@ siss.uol.edu.pk
}

Received: March 22, 2021

Published: December 31, 2021

\begin{abstract}
Pakistan and India are water stressed countries and the seed of water conflict between the two has been sowed by the Punjab boundary commission at the time of Partition. Trans-boundary water treaties have played a significant role in resolving the water disputes though the mechanism of conflict resolution varies and structurally fails to address the future problems that may arise. Indus Water Treaty (IWT) has been examined as an efficacious Model of conflict resolution and induced cooperation from 1960s to 1980s. Pakistan claimed that India is violating IWT by building dams and diverting waters of Western Rivers flowing from India to Pakistan. Therefore, the research attempts to answer the following questions. What is the cumulative effect of Indian dams being constructed on the Western Rivers? Can India Unilaterally withdraw the treaty? What would be the implications if India violates the treaty? Holistic content analysis of qualitative method and conflict theory has been used to investigate the water conflict between Pakistan and India. The key findings are that violation of treaty by India is perceived as security threat by Pakistan and also increase its economic concerns. The tension between the two neighbours over water sharing can lead to water war which poses serious threats to regional peace and security.
\end{abstract}

Keywords: Indus Water Treaty, Indus Basin, South Asian disputes, ecosystem, trans-boundary conflict, river disputes, water scarcity, regional security.

How to Cite: Munir, K., Khalid, I., \& Shahrukh, W. (2021). Water conflict between Pakistan and India: Implications to regional peace and security. Journal of Humanities, Social and Management Sciences (JHSMS), 2(2), 255-270. https://doi.org/10.47264/idea.jhsms/2.2.19

Publisher's Note: IDEA PUBLISHERS (IDEA Publications Group) stands neutral regarding jurisdictional claims in the published maps and institutional affiliations.

Copyright: $@ 2021$ The Author(s), published by IDEA PUBLISHERS (IDEA Publications Group).

Licensing: This is an Open Access article published under the Creative Commons AttributionNonCommercial 4.0 International License (http://creativecommons.org/licenses/by-nc/4.0/) 


\section{Introduction}

For the maintenance and sustainment of ecosystem, water is indispensable. The scarcity of water could spell increase conflicts in the water scarce region and South Asia in particular. The population growth and the climate change will make the problem worse. Due to increase in demand of water because of Industrialization, the competition to control fresh water may become a source of conflict and wars between states sharing water. Discussion about water in South Asia in particular the shared rivers of the region, is vociferous, antagonistic and increasingly associated with national security (Chatham House, 2014). The renewable freshwater resources increasingly fallen down in Pakistan and India. Both states share the water of Indus River Basin (IRB). The seeds of the conflict have been sowed at the time of Partition by Punjab Boundary Commission.

In violation of its mandate to demarcate the boundaries on the principle of geographical contiguity, the Madhopur and Ferozpur were allocated to India. Both were Muslim majority areas and should be allocated to Pakistan. As a result of this unfair demarcation of boundary, Pakistan become lower riparian and India the upper riparian and India got control of the maximum headwaters and the tributaries of IRB. Pakistan relies heavily for irrigation on those headwater and tributaries. India blocked the water from these channels of water supplies to Pakistan (Hussain et al., 2021). To resolve the issue, an agreement was signed in December 1947 which is known as standstill agreement. But the agreement does not survive so long and supply to Pakistan was cut off on 1st April 1948 due to which agricultural production was affected.

India demanded payment from Pakistan for the water by claiming the property right of water, but Pakistan objected to that by contending that it will only pay for maintenance and operation and not for the water that belongs to her before partition. Pakistan's posture was in line with the already signed treaties between different States and provinces of the subcontinent. The negotiations between the two states to resolve the issue take place but only after the involvement of the World Bank in 1952 and an agreement was signed which is called IWT in September 1960 (Bhatti, 2020).

The conflict over water between nuclear states i.e., India and Pakistan have the potential of escalating into a water war. The water conflict not only have regional but global ramification if both states fail to resolve the issue. The current pattern of constructions of dam by India is seen as security threats in Pakistan. The availability and increasing demand of water in Pakistan and the violation of IWT by India posed serious security and economic threats on the one hand and serious threats to regional peace and security on the other hand. The study examines the factors due to which both states could resort to war. The study suggests measure to address Pakistan's anxiety over access to water.

\subsection{Objectives of the study}

- To forestall the scarcity of water in Pakistan and its consequences in terms of threat to peace and security of the region in the future.

- To Examine the water treaty as a specimen of conflict resolution

- To ascertain the factors contributing to water tension between two states 


\subsection{Significance of the study}

The scarcity of water in South Asia, Middle East, and Africa and in some other parts of the world has heightened the threat of water war(s). There are trepidations within the academics, decision makers, politicians, journalist and practitioners about India's behavior to control the water. India being upper riparian can use it as tool against Pakistan during the times of flood. The construction of hydroelectric project by India has been perceived by Pakistan as violation of the treaty. The IWT is bilateral agreement that offers a framework to both countries for future cooperation to amicably resolve challenges of effective water management. The current research scrutinizes the treaty as an exemplary for conflict resolution by examining the factors which added more fuel to this conflict. The study also examines the possibility of unilateral revocation of treaty by India and its regional and global ramification. The current availability of water in Pakistan has generated security threats for Pakistan and study at the end suggests measures to address security threat emanates from water scarcity.

\section{Literature review}

The notable work on water and security was first published in the 1970 and 80 which includes: "Redefining security" by L. Brown (1977), 'Redefining Security' by R. Ullman (1983), and "An Expanded concept of International security" by A.H. Westing (1986). The main thesis of these papers was that most of the conflicts between states are to secure control over territory and natural resources which includes water too. If natural resources are in decline, conflicts are bound to increase. The conflict over water can be classified into five groups which include:

\begin{tabular}{|l|l|}
\hline Types of water conflicts & Explanation \\
\hline $\begin{array}{l}\text { Control of water } \\
\text { Resources }\end{array}$ & $\begin{array}{l}\text { Tran's boundary territories where supplies or access of water } \\
\text { between states is the cause of tension. }\end{array}$ \\
\hline Military Tool & $\begin{array}{l}\text { When this tension reached to level that the state parties } \\
\text { involved used it as weapon of military tool during wars. }\end{array}$ \\
\hline Political tool & $\begin{array}{l}\text { When the state parties or non-state actors used these water } \\
\text { resources, or water systems for political gain. }\end{array}$ \\
\hline Terrorism & $\begin{array}{l}\text { When these water system or water resources are targeted by } \\
\text { non-state actor as a tool of violence or coercion. }\end{array}$ \\
\hline Military target & $\begin{array}{l}\text { Where the state parties target the water resources or water } \\
\text { systems during military action. }\end{array}$ \\
\hline Development Dispute & $\begin{array}{l}\text { When both water resources, or water systems become a source } \\
\text { of disagreement and dispute due to development in deferent } \\
\text { sectors }\end{array}$ \\
\hline
\end{tabular}

Gleick in his article explains that if the supply of the resources is not according to demand to lower riparian and the upper riparian used it competitively, then each riparian will try to secure water. This leads to competition over the control of water and will intensify the existing hostility and can lead to water war (Gleick, 1993a: 9). The water issue between Pakistan and India is not the primary root of tension but after the Kashmir issue, it is the most contentious issue between both states. The Kashmir a disputes region from the distributed rivers flows under Indus water treaty and on many occasions when tensions heightened India has threatened to abrogate the treaty. 


\section{Theoretical framework}

According to the Conflict Management Theory each riparian will try to secure water. This leads to competition over the control of water and will intensify the existing hostility and can lead to water war (Gleick, 1993, p. 9). The water issue between Pakistan and India is not the primary root of tension but after the Kashmir issue, it is the most contentious issue between both states. The Kashmir is a disputed region from where the distributed rivers flow under IWT and on many occasions when tensions heightened India has threatened to abrogate the treaty (Mehsud et al., 2020; Hussain et al., 2021). The conflict management theory presents model of construing the conflicts and tools to resolve the problems arising between the countries due to the conflict. The conflict resolution method involves four stages i.e., negotiation, communication, mediation and arbitration. The Indus water treaty has been examined as conflict resolution tool between Pakistan and India through these steps.

On August 15, 1947, The British partitioned a subcontinent containing one sixth of the world's population into the modern nations of Pakistan and India. Eighteen years later, the undeclared war over Kashmir served as unpleasant reminder to the world that partition and independence had left much unfinished business in the subcontinent" (Michel, 1967). The Partition of the subcontinent into Pakistan and India is accepted as a final and permanent thing. If Pakistan feels that India or the United Nations or the USA is seeking by indirection to return Pakistan (piecemeal, perhaps) to India, she will meet every proposal with distrust and fear. Pakistan and India do not accept an armed truce as the natural relations, but that they integrate their economic and cultural life, become dependent on each other as neighbours, as are Canada and the United States (Rehman et al., 2018; Lilienthal 1951).

The Human rights to water pronounce that "states must guarantee the right of everyone to sufficient, safe, acceptable, physically accessible and affordable water for personal and domestic uses". The United Nations General Assembly (UNGA) recognizes it as "Basic Human Right" in 2010 through the initiative of Bolivia. The Trans boundary Basin "Comprise nearly $50 \%$ of the land area, are home to $40 \%$ of the world population and generate nearly $60 \%$ of available fresh water" (Giordano \& Wolf, 2003). The Trans boundary water resources and the competition between the states to get control over it have made it a matter of International Security. In this context, the human rights to water have established certain guideline for states to follow. From the guideline we can draw certain conclusions:

- The states are the guarantors of the human rights to water within its territory and while respecting and implementing it. It should prevent any domestic or foreign elements from limiting the right of water to any sector or community within its territory.

- The key element in this aspect is the cooperation between the states who are sharing water resources. They should ensure human right to access water not only within its territory but also in the neighbouring countries through the policies of cooperation.

- The states should refrain from using water as a weapon of political and economic pressure against other states.

\section{Data sources and material}

The current study is analytical research which utilizes secondary data officially published by Pakistan Indus Commission, international water management institute, World Bank, United 
Nation Organization and the governments of both India and Pakistan. The study used the India office records and private papers available at British Library London which are most extensive archives relating to subcontinent history. The information collected from books and articles from the library of London School of Economics has been utilized in this research.

\section{Indus Water Treaty: To resolve water dispute between Pakistan \& India}

\subsection{The Treaty}

The treaty is a short document of twelve articles, a short preamble with the eight sumptuous Annexures, and four appendices. But the intricate and verbose due to annexures attached to it are highly technical and provide grounds for future disagreements. Ramaswamy Iyer views about the technical nature of the treaty, "it provides ample opportunities for differences among engineers. The water sharing treaties between India and Nepal and India and Bangladesh are non-technical and even non-engineers can understand the terms of the treaties. The appendices and Annexures of the IWT treaty are technical and opaque in nature. This very nature of the treaty provides grounds for the future disagreements between the two states (Indus Treaty, 2005, p. 3140).

The Second notable features that distinguish it from other international water treaties that apart from Pakistan and India, The World Bank (WB) is also Party to it. Being a Party to the Treaty, however does not signifies that the WB enjoys the same judicial status as Pakistan and India because, unlike them, it is bound only by articles $\mathrm{V}$ and $\mathrm{X}$ which respectively relates to the financial and emergency provisions: and Annexures F, G, and $\mathrm{H}$ which respectively relates to the role of Neutral Expert, the Court of Arbitration, and transitional arrangements (Hussain, 2017, pp. 187). The article $\mathrm{V}$ and Annexure $\mathrm{H}$ which dealt with transitional and financial arrangements now become redundant as WB have accomplished these obligations and now it is only bound by Adjudicative provisions of Annexures F and G. The Third conspicuous feature of the treaty is not water sharing but water portioning treaty which divides the rivers between Pakistan and India. This feature also distinguishes it from other International Water Treaties relating to global drainage basins because they share the waters of common rivers between Riparian states instead of dividing between the Riparian states.

\subsubsection{Provisions of treaty regarding the division of the rivers}

a) The treaty allocated the three Eastern Rivers (Ravi, Sutlej and Beas) to India for unrestricted use and barred Pakistan from interfering in the waters of these three rivers and their tributaries when they flow from Pakistan except for domestic, non-consumptive (any use or control of water for beneficial purposes), and certain limited agricultural uses.

b) The treaty allocates the same rights to Pakistan of the Western Rivers (Chenab, Jhelum and Indus) and obligations to India related to use of water of these three rivers. But as these rivers flow from India, Treaty allows India to use water for electricity generation and to build storage of maximum 3.6 MAF within the defined parameters outlined in detailed in Annexure C, D and E.

\subsubsection{Issues and obligations on Pakistan and India under treaty}

Pakistan and India both have reservations regarding interpreted and increase supply of water 
which treaty tries to resolve through different provisions of the treaty. But at the same there are provisions which are vague specifically the one which deals with water pollution. The treaty binds each party to prevent undue pollution of Indus Rivers and to take equitable measure to ensure that before any sewage or industrial waste flow into them, it is treated that it should not affect its uses: the criterion of reasonableness that the Treaty has laid down is the customary practice in similar situation (article IV). The Term "undue pollution' and criterion of "reasonableness" have not been defined and did not take into account the future pollution problems that will arise due to Industrialization, urbanization, rapid population growth. The Provision could be the source of tension between the two, especially when the Pakistan is the lower riparian state.

\subsubsection{Conflict resolution mechanism in the treaty}

The Treaty established a Permanent Indus Commission (PIC) for information exchange and to further cooperation to avoid any conflict. It postulates that both states would appoint an engineer who should be an expert in hydrology and water-use. The appointed engineers will be government representatives if any issue occurs in the course of treaty implementation to their respective governments. The two commissioners constitute the permanent Indus Commission, and it has to take an inspection tour in every five years for determining the evidence concerned with the development works on the rivers. The treaty obligates both states to accord the privilege and protections which are permitted to the representatives of member states under section 11, 12, and 133 of article of 1946 Convention on the privileges and immunities of the UN (Article VIII, paras, 5, 6).

If during the implementation or interpretation of the treaty a dispute or difference arises between the member states, they can resort to article IX of the treaty. According to the article Commission will resolve the issue. If the commission fails to address the 'question' the 'difference' is deemed to have arisen. Then either of the commissioners may request for the appointment of the Neutral Expert by agreement as entitles by the treaty. If the neutral expert opines that the 'difference' should be treated as 'dispute' in accordance with the provisions of paras. 3, 4 and 5 of article IX then commission report the facts to the two governments stating the points of disagreements and agreements and their explanation of the issue and its justifications. In such condition the seven-member arbitral tribunal called 'Court of Arbitration' would take care for it.

Table: Procedure to handle the issues detailed in treaty and the cases for those these methods have been used:

\begin{tabular}{|c|c|c|c|}
\hline $\begin{array}{l}\text { Categories of } \\
\text { issues }\end{array}$ & Methods & Composition & Cases \\
\hline Questions & Commission & Two members constitute IC. & Salal Dam case \\
\hline Differences & Neutral Expert & $\begin{array}{l}\text { Both Parties appoint him with agreement } \\
\text { and if fail to do so, Bank is then entrusted } \\
\text { to do so. Annexure F lists } 23 \text { questions } \\
\text { which falls within the preview of NE. }\end{array}$ & Baglihar case \\
\hline Disputes & $\begin{array}{l}\text { Court of } \\
\text { Arbitration }\end{array}$ & $\begin{array}{l}\text { Article IX (5) and Annexure } G \text { of the treaty } \\
\text { deals with role of the Court of Arbitration. }\end{array}$ & $\begin{array}{l}\text { Kishenganga } \\
\text { case }\end{array}$ \\
\hline
\end{tabular}




\subsubsection{Implementation of the Treaty}

From the ratification of the treaty in 1960 to 1970 there was not a single water issue between the two countries. In the first decade of the treaty, Pakistan has constructed dams (Mangla, Terbela), barrages and Link canals on the Eastern Rivers but didn't build any structure on the western Rivers. The issues pop-up when India decided to build dams for electricity generation purpose on western Rivers. Following are the water dispute erupted between the two states and the number likely to increase in future as India has planned a series of such projects which are in various stages of implementation (Hussain, 2017).

\begin{tabular}{|l|l|l|l|}
\hline Projects & Dams \& Spillways & Location of the project & $\begin{array}{l}\text { Status of the } \\
\text { dispute }\end{array}$ \\
\hline Salal Dam (1970) & $\begin{array}{l}\text { 690 MW } \\
\text { hydroelectricity }\end{array}$ & $\begin{array}{l}\text { Chenab River in } \\
\text { Udhampur in Jammu }\end{array}$ & Settled \\
\hline $\begin{array}{l}\text { Wullar Barrage/Tulbul } \\
\text { navigational project } \\
(1980)\end{array}$ & 439 feet long barrage & $\begin{array}{l}\text { Jhelum River in } \\
\text { Bandipore district in } \\
\text { north of Srinagar }\end{array}$ & Unresolved \\
\hline Baglihar Dam (1992) & 450 MW power plant & $\begin{array}{l}\text { Chenab River in Doda } \\
\text { district in Jammu \& } \\
\text { Kashmir }\end{array}$ & $\begin{array}{l}\text { Operational } \\
\text { (though Pakistan } \\
\text { has serious } \\
\text { reservation) }\end{array}$ \\
\hline Kishenganga Dam & $\begin{array}{l}\text { Kishenganga } \\
\text { Hydroelectric Project } \\
\text { (KHEP) }\end{array}$ & $\begin{array}{l}\text { Jhelum River in parts of } \\
\text { Jammu \& Kashmir }\end{array}$ & $\begin{array}{l}\text { Operational (court } \\
\text { decided in favour } \\
\text { of India) }\end{array}$ \\
\hline $\begin{array}{l}\text { Nimoo Bazgo and Chutak } \\
\text { Dams (2005) }\end{array}$ & 45 MW power plant & $\begin{array}{l}\text { Indus River from 70 } \\
\text { Km from Leh }\end{array}$ \\
\hline
\end{tabular}

\section{The factors threatening to contribute to water war and the revocation of the treaty}

The examination of the variables that can contribute to increase tension between the two states is prerequisite and the importance of IWT as barrier against intensified conflict over water resources.

\subsection{Kashmir conflicting point between the two states}

The Kashmir is a contentious issue between Pakistan and India since 1947. The rivers flow from the disputed region of Kashmir of which both Parties claim their rights. The crafters of treaty carefully handle the issue by bypassing it through the article XI, Para 1. It states that "it governs the right and obligations of each party in relation to the other with respect only to use of the waters of the rivers. It further elaborates that 'shall be constructed as constituting or waiver of any rights or claims whatsoever of either of the parties other than those rights or claims which are expressly recognized or waived in this treaty" (Hussain, 2018).

B. Iliff Chief negotiator wrote letter to N. D. Gulhati,

The Bank Approach was two prongs that no party should gain for its principle stand on Kashmir or should seek to erode the principal position of the other party from the treaty. However, both parties disagree on the scope of the article XI, and it's been highlighted during Kishenganga case where Pakistan objected it. 


\subsection{Water scarcity}

The increasing water scarcity at global level has made a ferocious antagonism over the control and access of water resources not only between countries but within the country also. This behavior of the states especially those who are economically and militarily strong has generated a debate over the sharing of trans-boundary water and prospects of conflict over water. The Trans-boundary Rivers could be flash points and can become source of conflict between nations which could cause disruption in the infrastructures.

The $97.21 \%$ water on the planet is which is not usable and $0.62 \%$ is aquifer of the fresh water which is $2.79 \%$. For the people available water per capita is 1329 Cubic Meters and only $0.03 \%$ is for human consumption. The Trans boundary river basins are 263 in the world and aquifer are in hundreds on which the population the whole world depends. The Indus Basin is the second most overstressed and being depleted without getting recharged. Pakistan's available per capita water is 1000 cubic meter to qualify as water stressed country and as per the reports of the United National Development Program Pakistan will be water scarce country by 2025 .

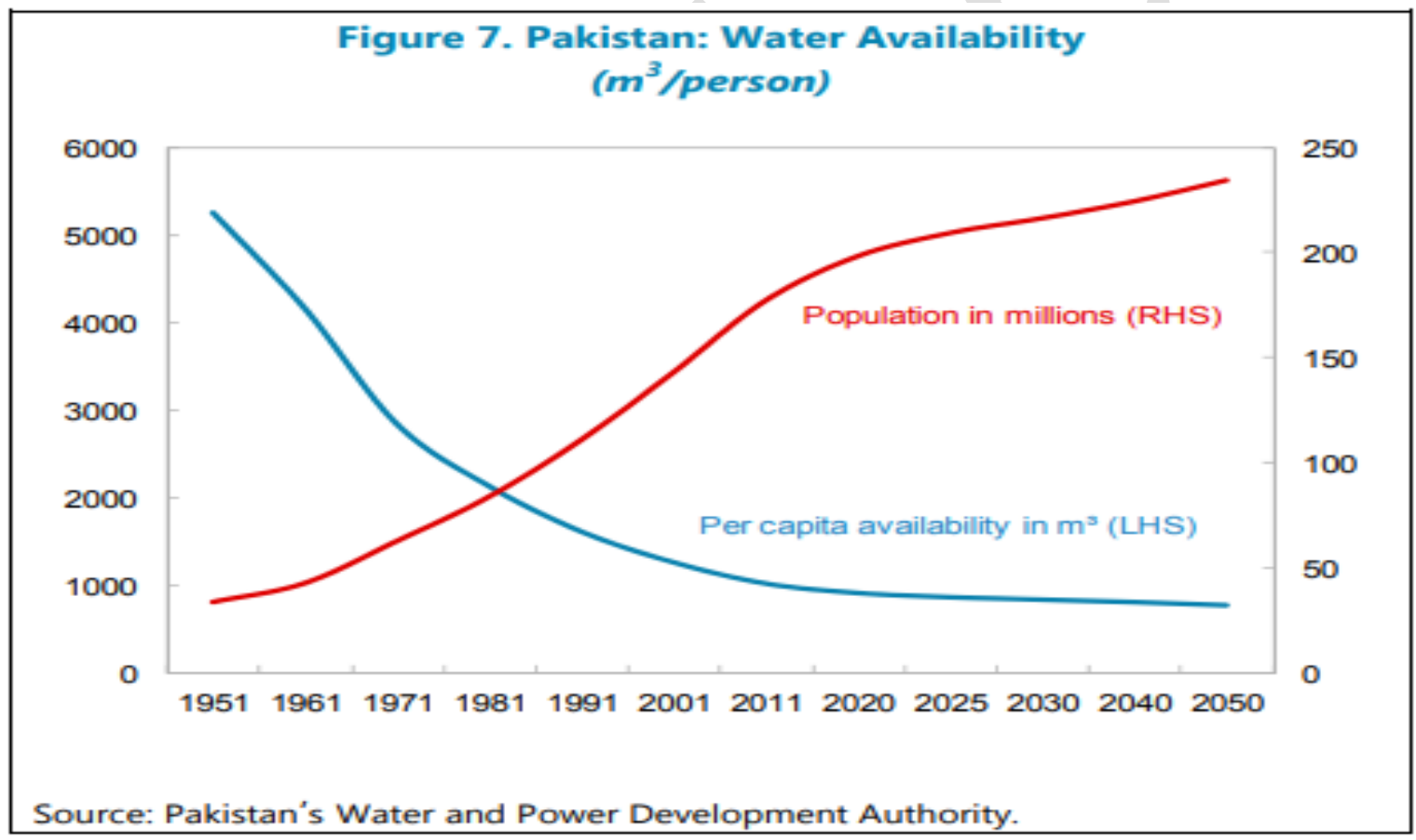

Being an agricultural country Pakistan depends on the water which makes the situation critical. The issue has become has complex because rivers that flow into Pakistan from the territory over which both the state have fought war and it is still bone of contention between the two. And after the signing of China Pakistan Economic Corridor (CPEC) which entails multiple industrial and agricultural projects the need of water increases is a reason behind increased water insecurity (see, Ali et al., 2019; Ahmad et al., 2020).

\subsection{Climate change}

The IWT has proved to be a successful water-sharing formula by providing an abstemiously 
framework for conflict resolution however the climate change putting stress on the sustainability of the treaty. "The water sharing mechanism lacks guidelines to cater the issues related to climate change and basin sustainability which require integrated approach for their address" (Qamar et al., 2019, p. 4). Indus Basin is highly dependent on water derived from the melting of snow and glacier in the upper part of the basin. The impact of global warming on the accessibility of water has generated a heated debate on "Rights versus Needs". The climate change has reduced the flow of water in the IRB. It is predicted that the rivers in IRB may become seasonal rivers by the 2040. The factors which are impacting the quantity and flow of water includes: melting of glaciers due to global warming and these melted glaciers bring great amount mid with them. Due to the mud, the holding capacity of water reservoirs is now reduced on both sides (Chaturvedi, 2018; Jan et al., 2020).

Table: Glacial / snow / Monsoon Melt in IB

\begin{tabular}{|l|c|c|c|l|}
\hline \multirow{2}{*}{} & $\begin{array}{l}\% \text { of IRS } \\
\text { inflow }\end{array}$ & \% Seasonable distribution & \multicolumn{2}{l|}{$\begin{array}{l}\text { Dominant source } \\
\text { of flow }\end{array}$} \\
\cline { 2 - 5 } & Summer & Winter & Glacial melt/ snow \\
\hline Indus & 44 & 86 & 14 & $\begin{array}{l}\text { Glacial melt/ snow + } \\
\text { Monsoon }\end{array}$ \\
\hline Chenab & 19 & 83 & 17 & $\begin{array}{l}\text { Mainly snow melt + } \\
\text { monsoon }\end{array}$ \\
\hline Kabul & 16 & 78 & 22 & Glacial melt/ snow \\
\hline Others & 16 & 82 & 18 & ----- \\
\hline
\end{tabular}

Sources: Complied by the researcher

Pakistan main source of water supply is the Indus and its tributaries, and its water comes from the glacier and snow melt in the Himalayas. The $85 \%$ of its flow occurs during June to September and overlaps with the concentration of rainfall in Monsoon. The rainfall varies in different parts of Pakistan, in Punjab $1500 \mathrm{~mm}$ to $150 \mathrm{~mm}$ in Sindh. Due to vary weather conditions Pakistan faces floods and droughts that cause significant mutilation to the agricultural and water infrastructure. These are due to absence of passable water reservoirs. Total dam storage in Pakistan represents only 30 days of average demand, compared to 1,000 days for Egypt and 220 days for India (IMF, 2015).

The construction Wullar Barrage by India irrespective of its purpose could endanger vast tracts of agricultural land in the Pakistani Punjab. The consequence of the project lies in the fact that once it is materializing; it could provide India with the mean to intimidate Pakistan by releasing water that could ruin the entire triple canals project (Upper Jhelum Canal, Upper Chenab Canal and the lower Bari Doab Canal).

\section{India's behaviour is a threat to the existence of the Treaty}

Shafaqat Kakakhel, chairperson of the Strategic division planning and investment opines on this matter, "Pakistan susceptibility about India's behaviour is based on worst case scenario rather than on credible assessment of India's capability to change the flow of western rivers". In 2019, while addressing a campaign rally in Haryana, Modi promised the farmers of Punjab that his government will stop the water flow and divert the water into the state. Pakistan government reacted to it by saying that any attempt to stop water flow of the Indus would be considered as an act of aggression. This is not the first time that India has threatened to scrap 
the treaty, it was deliberated by Indian government in 2002 after the Parliament attack, 2016 after the Uri skirmish when Modi while referring to the treaty said that "blood and water cannot flow together".

\subsection{The Question arises that why would India want to scuttle the Treaty?}

The first is very mush evident from World Bank Report that India is increasingly becoming water-deficit country attribute population growth. With The current available water resources, it cannot its future needs. The second is to keep Pakistan under pressure for security reasons. The construction of dams in Indian part of Kashmir is an indication that Indian can use it at any given to stop the flow of western rivers to strangle Pakistan. Pakistan is an agricultural country and highly dependent on Indus River and without water would be a desert.

\subsection{Can India unilaterally withdraw from the treaty?}

To answer this question, analysis need to be done from three dimensions i.e., legal, political, and economic (Structural/institutional Capacity).

\subsubsection{Legal}

No state can withdraw itself from a bilateral treaty or abolish or violate the treaty unilaterally. The United Nations Convention on Civil and Political Rights (ICCPR) also preclude India from filibustering Pakistan's access to water. Any prevention of water could be termed as violation of basic human rights which is essential for human survival (Qureshi, 2016). The International Law Commission (ILC) in its an official commentary elucidated the reasons to sack or leave from a treaty: "The formula 'invoke as a ground' is intended to underline that the right arising under the article is not right arbitrarily to pronounce the treaty terminated" (Brilmayer 2010). To invoke article 46 for the termination of the treaty India would have to produce possible reason that whether any clause of the treaty violates or in contrast with the International Law of fundamental importance. If India used it as reason, then the question could be raised that why it has not raised earlier despite that India is planning and utilizing water works under same provision for decades.

\subsubsection{Political}

In the term of the realpolitik, the India's unilateral decision to withdraw from treaty will damage its global reputation and will not go well with its neighbouring countries with which India has signed treaties on water sharing. There have been debates over India's prospects of withdrawing from treaty on national and international media, but the analysis of the history shows that India has only used it to threat and pressure to bow down Pakistan on the issue of Kashmir. "India is well aware of the political implication of this action that could include the criticism from world powers besides weakening Indian position in relation to other riparian states in the region" (Yaqoob, 2017). If India pulls out of the treaty, then it had to do what international obligates the Upper Riparian stats to do vis-à-vis water flow.

\subsubsection{Institutional capacity}

Ramaswamy Iyer writes that India did not have the institutional capacity to build reservoir to 
store water from Indus. He further argues that can proceed with the building of storages on the western rivers, but these projects would take years (10 or even15) to build. There is no nippy or easy way to divert the waters of these rivers. The India cannot change the flow of the river or neither it can build barriers across the rivers whether they are allocated to India or Pakistan. The all six rivers continue to flow into Pakistan and then into Arabian Sea. The abrogation of treaty by India can only invoke international criticism which will not go well with India.

\section{IWT efficacious illustration of "Conflict Resolution"}

The Treaty still intact despite the various disputes related to water sharing and has survived wars that broke out between Pakistan and India. Both countries even observed the treaty conscientiously during the bad phases of their relations. The IWT is unique considering that it was crafted, signed and implemented by India and Pakistan despite its conflicting location but its location could prove to be challenging in the future for the existence of the treaty. Population growth, Climate change, technology are the factors that are now shaping the geography other than location. These factors are not discussed and deliberated by the formulators of the treaty. In the context of Kashmir, the opinion of the people of both parts of Kashmir is important other than the geo-political consideration. How they view the construction of the dams by both states and their aspirations are not taken care of in IWT. Due to geo-political dynamics, The IWT can only defer the leeway of future conflict does not eliminate it.

The treaty as we have discussed above didn't cater the socio-economic changes, environmental degradation, increase urbanization which are caused by increased population. The environmental degradation can affect the water flow in the western rivers. Consequently, colossal deforestation, pollution and drainage system getting blocked due to trespassers and effect on the water availability (see, Aslam et al., 2021). The following table shows that availability of water has decreases considerably while demand increase which justified Pakistan concerns regards the misuse of India to grab more water from Indus Basin.

Table: Water availability in India and Pakistan

\begin{tabular}{|l|l|l|l|l|}
\hline $\begin{array}{l}\text { Water } \\
\text { availability }\end{array}$ & $\begin{array}{l}\text { Pakistan } \\
\text { (cubic feet) }\end{array}$ & Population & $\begin{array}{l}\text { India } \\
\text { (cubic feet) }\end{array}$ & Population \\
\hline 1960 & 5000 cubic feet & 50 million & 6000 & 165 million \\
\hline 2016 & 1500 cubic feet & 200 million & 1600 & 1268 millions \\
\hline
\end{tabular}

Source: Compile by researcher

\section{Implication of water conflict on South Asia security}

Water as a tool to intimidate the rivals is not new; it has been used as a security policy by various states in the Past to influence their adversaries by cutting or diverting the flow of common water resources. Such conflict has led concerned stake holders to go for dispute resolution through battle. The energy and food security of country also affected by shortage of water and its worsening with exhausting water resources and had a full potential to trigger conflict in future (see, Idrees et al., 2017).

Since the ratification of the treaty the parties resorted to all three-method envisaged in the treaty to resolve the conflict. In the Salal Dam Case, both parties settled the issue through bilateral negotiations by determining it as 'question'. In the Baglihar Case, both parties determine the 
issue as 'difference' and sought the help of neutral expert. In the Kishenganga Case, the court of arbitration reckoned both the issues involved as 'disputes. The progression of issues from question to difference and arbitration shows that the conflict over water has been worsening with the time between the two nuclear states. In view of the Pakistan dependence on Indus Waters for irrigation and human consumption if India cut off or reduce the water flow its implication could be catastrophic for Pakistan's water security.

Pakistan views the construction of Dams and reservoirs spree on the western rivers for the purpose of power generation with the capacity to withhold or reduce water at critical moment as a threat to its water security. On the other side, India rejects this charge and deems that these projects are strictly in accordance with the terms of the treaty. John Briscoe opines that, "if India were to erect several large hydroelectric dams on the Western Rivers, then Pakistan's agriculture could conceivably lose up to a month's worth of river flow---which could ruin an entire planting season. Still, it would not be nearly as serious as catastrophes that could ensue if India pulls the plug on the IWT".

\section{Conclusion}

The peaceful resolution of water conflict is prerequisite for building good relations between the two nuclear powers of South Asia. The Portioning of the Indus Rivers System between the two nuclear south Asian States though they were not nuclear at the time when the treaty was signed but an adherence to the treaty explains the success of the treaty and absence of an armed conflict on water issue (Hussain, 2017, p. 188). Due to contentious relations between Pakistan and India, "water has become subjected to deveolopmental nationalism and geostrategic calculation. This "go-it-alone approach" fosters mistrust and feeds a security spiral" (Vater, 2021). "As a cooperative water management mechanism, IWT is far from satisfactory to both India and Pakistan. Uncertainties over the interpretation of the treaty on infrastructure development in the western rivers have become a major source of friction in regular intervals between India and Pakistan (Swain, 2017).

As far as the implication of water conflict is concerned a skirmish at border and Balakot type strike to get international attention is possible but there is little chance of a full-scale conventional war. Escalation to the nuclear level is highly unlikely too because economic threshold might not apply in full in such a case. A simple rejection can be sought from the fact that if Kashmir (an established nuclear flash point) hasn't led to nuclear conflict, especially since the annexation, then so can't water. But of course, if you go in depth, there are several factors which support and negate the hypothesis of a water war. There hasn't even been a conventional or small war over water; so, a nuclear escalation over water is out of purview for now. But yes, it could be a complimentary or subsidiary factor in a situation which has already been taking India-Pakistan towards the nuclear option. This is an existential crisis. Those who want it to be the central dish at the dining table of international strategic milieu; they may label it in the form of water wars, It may lead to conflict of interests but not to war.

\section{Recommendations}

The shortcomings of the IWT arguably highlight the need for the development of International Laws to govern trans-boundary rivers and lakes, comparable to the United Nation Laws of the Sea (Abas et al., 2019). In the context of climate change, need to take pre-emptive action 
against natural disasters such as flooding or drought, which are becoming more frequent and intense (Climate Diplomacy, 2020).

Water stress in Pakistan is expected to increase in future due to rapid increase in population, environmental degradation, increasing water consumption. If not dealt with the problem, it will put severe strain on Pakistan's economy and could further strain Pakistan's relations with India. The implementation of Pakistan national water policy (NWP) is perquisite which highlights a mechanism for sharing Trans-boundary aquifers and joint watershed management. It also promises to address Pakistan's water-related issues owing to Trans-boundary water releases and stoppages.

The NWP proposed a study within the framework of IWT and international water laws to evaluate the impact of construction of hydropower project by India on western rivers. The NWP also promised to explore the options to preserve the environmental integrity of the Indus River system and ecological consequences as a lower riparian to minimize the threats faced by population of the areas located on the sides of eastern rivers due to diversion of flow of these rivers by India for irrigation and other purposes.

Internally to have security from water and security for water:

Firstly, an integrated approach with an inclusive policy on the conservation of sustainable water through infrastructure up gradation, improved cost recovery mechanism and brining agriculture sector under the tax regime.

Secondly, Pakistan needs to increase investment in water infrastructure which was historically built to cater the agricultural needs, but today due to rapid urbanization and industrialization water infrastructure is mandatory to supply safe drinking water and sanitation. The construction of small dams and hydropower projects as mentioned in the National Water Policy.

Other important factors that need consideration is River Kabul which adds 21MAF to the Indus River, but no legal mechanism has been designed by neighbouring states on water sharing. Pakistan and Afghanistan should start negotiations on the sharing and management of river.

\section{References}

Abas, N., Khan, N., Saleem, M. S., \& Raza, M. H. (2019). Indus Water Treaty in the Doldrums Due to Water-Power Nexus. European Journal for Security Research Volume, 201242. https://link.springer.com/article/10.1007/s41125-019-00043-y

Abbasi, A. (2012, January). Indus Water Treaty between India and Pakistan. PILDAT. https://cyphynets.lums.edu.pk/images/Indus_Water_Treaty_Reading.pdf

Abubakar, S. M. (2018, September 14). Pakistan's water woes: Assessing the national water policy. The Express Tribune. https://tribune.com.pk/story/1795801/pakistans-waterwoes-assessing-national-water-policy

Ahmad, S., Syed, A., Bhutta, M. M. (2020). Indian Inclusion in CPEC: A Path to Indo-Pak Threat Reduction via Complex Interdependence. Liberal Arts and Social Sciences International Journal (LASSIJ), $\quad 3(2), \quad 11-19$. https://doi.org/10.47264/idea.lassij/3.2.2 
Water conflict between Pakistan and India: Implications to regional peace and security

Akhter, M. (2017). More on the Sharing of the Indus Waters. Economic and Political Weekly, 45(17), 112-122. https://www.epw.in/journal/2010/17/discussion/more-sharingindus-waters.html

Ali, R., Ali, I., Ullah, S. (2019). SCO as a passage to regional security: Future developments and opportunities for Pakistan. Liberal Arts and Social Sciences International Journal (LASSIJ), 3(1), 19-29. https://doi.org/10.47264/idea.lassij/3.1.3

Aslam, B., Gul, S., \& Asghar, M. F. (2021). Evaluation of environmental degradation as an unprecedented threat to human security in Pakistan. Liberal Arts and Social Sciences International Journal (LASSIJ), 197-211. https://doi.org/10.47264/idea.lassij/5.1.14

Bhatti, M. N. (2020). Politics of Water Resource Management in the Indus River Basin: A Study of the Partition of Punjab. Liberal Arts and Social Sciences International Journal (LASSIJ), 4(2), 60-70. https://doi.org/10.47264/idea.lassij/4.2.6

Briscoe, John; Qamar, Usman. 2008. Pakistan Pakistan's Water Economy: Running Dry. Water P-Notes; No. 17. World Bank. https://openknowledge.worldbank.org/handle/10986/11746

Chatham House, The Royal institute of International Affairs. (2014, June). Attitudes to Water in South Asia. https://www.chathamhouse.org/sites/default/files/field/field_document/20140627W aterSouthAsia.pdf

Chaturvedi, A. K. (2018). Indus Water Treaty: An Appraisal Voices on Indus Water Treaty at Different Points in Time. Vivekananda International Foundation, 1-25. https://www.vifindia.org/sites/default/files/indus-water-treaty-an-appraisal.pdf

Climate Diplomacy. (2020). Water conflict and cooperation between India and Pakistan. https://climate-diplomacy.org/case-studies/water-conflict-and-cooperation-betweenindia-and-pakistan

Dawn. (2016, November 26). Modi threatens to use water as weapon against Pakistan. https://www.dawn.com/news/1298707/modi-threatens-to-use-water-as-weaponagainst-pakistan

Dawn. (2016a, November 25). “Water belonging to India cannot go to Pakistan," says Modi. https://www.dawn.com/news/1298575/water-belonging-to-india-cannot-go-topakistan-says-modi

Ebrahim, Z. T. (2018, May 5). Pakistan's first national water policy - historic or mere electioneering? DAWN. https://www.dawn.com/news/1406383

Gilmartin, D. (2015). Blood and Water: The Indus River Basin in Modern History (1st ed.). University of California Press.

Gleick, Peter H., (1993a), "An Introduction to Global Water Issues” in Gleick, Peter H., (ed) (1993), Water in Crisis: A Guide to the World's Fresh Water Resources. Oxford University Press: New York. pp. 3-12.

Hussain, M., Khalid, M., \& Imran, S. (2021). Hydro-Hegemony Framework: A study of the India Pakistan trans-boundary water competition and cooperation. Liberal Arts and Social Sciences International Journal (LASSIJ), 5(1), 539-555. https://doi.org/10.47264/idea.lassij/5.1.35

Hussain, S., Haheem, F., \& Islam, S. U. (2021). Impact of Hydro-Politics and Kashmir issue on bilateral relations of India and Pakistan. Journal of Humanities, Social and Management Sciences (JHSMS), 200-213. https://doi.org/10.47264/idea.jhsms/2.1.17 
Hussain, I. (2017). Indus Water Treaty: Political and Legal Dimensions (1st ed., Vol. 1). Oxford University Press.

Idrees, M., Naazer, M. A., \& Ashfaq, S. (2017). Conflicts and Conflict Management in SAARC: Assessing Challenges and the Way Forward. Liberal Arts and Social Sciences International Journal (LASSIJ), 1(2), 1-11. https://doi.org/10.47264/idea.lassij/1.2.1

Iyer, R.R (2005). Indus Treaty: A Different View. Economic and Political Weekly. 40. 31403144. https://doi.org/10.2307/4416904

Kakakhel, S. (2018, May 8). Opinion: Pakistan's new National Water Policy is historic. The Thirdpole. https://www.thethirdpole.net/2018/05/08/pakistan-national-water-policy/

Jan, A., Khan, T. A., \& Mehsud, M. I. (2020). The Climate Change Awareness and Literacy in Pakistan: Role of Media and Social Actors. Liberal Arts and Social Sciences International Journal (LASSIJ), $\quad 4(2), \quad$ 256-266. https://doi.org/10.47264/idea.lassij/4.2.20

Iyer, R. R. (2003). Water perspectives, Issues concerns. SAGE Publications. https://doi.org/10.4135/9788132103813

Iyer, R. R. (2010). Pakistan's Questionable Move on Water. Economic and Political Weekly, 45(13), 10. https://doi.org/10.2307/25664268

Mehsud, M. I., Jan, A., \& Khan, T. A. (2020). War or Peace on the Rivers of South Asia? Liberal Arts and Social Sciences International Journal (LASSIJ), 4(1), 242-254. https://doi.org/10.47264/idea.lassij/4.1.21

Kugelman, M. (2016, October 30). Why the India-Pakistan War Over Water Is So Dangerous. Foreign Policy. https://foreignpolicy.com/2016/09/30/why-the-india-pakistan-warover-water-is-so-dangerous-indus-waters-treaty/

Kugelman, M. (2016, September 30). Why the India-Pakistan War Over Water Is So Dangerous. Foreign Policy. https://foreignpolicy.com/2016/09/30/why-the-indiapakistan-war-over-water-is-so-dangerous-indus-waters-treaty/

Mirza, M. N. (2016). Indus Water Disputes and India-Pakistan Relations. Doctoral dissertation, Department of Political Science South Asia Institute University of Heidelberg Federal Republic of Germany.

Pant, S. D. (2012). Water Politics on Nepal's Fresh Water. Institute for Rural Development.

Pérez-Martín, M. Á. (2017). Security and Human Right to Water in Central Asia. Palgrave Macmillan US, 2017.

Polgreen, L., \& Tavernise, S. (2010, July 20). Water Dispute Increases India-Pakistan Tension. The New York Times. https://www.nytimes.com/2010/07/21/world/asia/21kashmir.html?_r=1

Qamar, M. U., Azmat, M., \& Claps, P. (2019). Pitfalls in transboundary Indus Water Treaty: a perspective to prevent unattended threats to the global security. NPJ Clean Water, 2-22. https://doi.org/10.1038/s41545-019-0046-x

Qureshi, W. A. (2016, December 26). The Indo-Pakistan water conflict. The News. https://www.thenews.com.pk/print/174428-The-Indo-Pakistan-water-conflict

Qureshi, W. A. (2017). Water as a Human Right: A Case Study of the Pakistan-India Water Conflict. The Penn State Journal of Law \& International Affairs, 5(2), 376. https://elibrary.law.psu.edu/cgi/viewcontent.cgi?article=1166\&context=jlia

Rashid, Z. \& Hilali, A. Z. (2020). Geo-politics of Most Favoured Nation (MFN) status under the WTO and future of trade between India-Pakistan. Liberal Arts and Social Sciences International Journal (LASSIJ), $\quad 4(1), \quad 54-65$. https://doi.org/10.47264/idea.lassij/4.1.6 
Rehman, A. U., Ashfaq, S., \& Khan, T. M. (2018). Kargil Operation and its Effects on the Civil-Military Relations in Pakistan. Liberal Arts and Social Sciences International Journal (LASSIJ), 2(2), 10-21. https://doi.org/10.47264/idea.lassij/1.2.2

Qureshi, W. A. (2016, December 26). The Indo-Pakistan water conflict. The News International. https://www.thenews.com.pk/print/174428-The-Indo-Pakistan-waterconflict

Rai, A. (2016). India's Strategy about Indus Waters Treaty. Economic and Political Weekly, 51(40). https://doi.org/10.2307/25664268

Rossi, C. (2019). Blood, Water, and the Indus Waters Treaty. SSRN Electronic Journal, 100110. https://doi.org/10.2139/ssrn.3510327

Sinha, R. (2006). Two neighbours and a treaty: Baglihar project in hot waters. Economic and Political Weekly, 606. https://doi.org/10.2307/4417834

Swain, A. (2017). Water Insecurity in the Indus Basin: The Costs of Noncooperation. In Imagining Industan: Overcoming Water Insecurity in the Indus Basin (pp. 37-48). Springer.

IMF. (2015, June). Issues in managing water challenges and policy instruments: regional perspectives and case studies. International Monetary Fund. https://www.imf.org/external/pubs/ft/sdn/2015/sdn1511tn.pdf

The News. (2016, November 26). Modi threatens to turn Pakistan into desert. https://www.thenews.com.pk/print/167830-Modi-threatens-to-turn-Pakistan-into$\underline{\text { desert }}$

The World Bank. (2018, June 11). Fact Sheet: The Indus Waters Treaty 1960 and the Role of the World Bank. https://www.worldbank.org/en/region/sar/brief/fact-sheet-theindus-waters-treaty-1960-and-the-world-bank

Vater, J. J. (2021). The Indus Waters Treaty: Prospects for India-Pakistan Peace. ISAS Working Papers. https://www.isas.nus.edu.sg/papers/the-indus-waters-treatyprospects-for-india-pakistan-peace/

Young, W. J., Anwar, A., Bhatti, T., Borgomeo, E., Davies, S., Gartwaite III, W. R., Gilmont, E. M., Leb, C., Lytton, L., Makin, I. M., \& Saeed, B. (2019). Pakistan Getting more from water. http://hdl.handle.net/10986/31160

Yaqoob, A. (2017). India Turning Many Tables for Indus Waters Treaty. Economics \& Political Weekly, 50(38). https://www.epw.in/journal/2017/38 